\title{
Palaeoclimate change during Glacial Periods: Evidence from Sri Lanka
}

\author{
J. Katupotha \\ Department of Geography, University of Sri Jayewardenepura, Nugegoda, Sri Lanka
}

Date Received: 24-11-2012 Date Accepted: 16-02-2013

\begin{abstract}
In the Earth's history, there were five major glaciations, namely, Huronian (2,300 Ma), Cryogenianor Sturtian-Varangian(850-635 Ma), Andean-Saharan (460-430 Ma, Karoo (360-260 Ma) and the Quaternary (2.58 Ma to Present) that occurred between 2,300 Ma and 0.0114 Ma. It is revealed that Gondwanaland emerged between the Huronian glaciation (2300-2100 Ma) in the Paleoproterozoic Era and the Andean-Saharan glaciation (460-420 Ma) in the Early Paleozoic Era. During this time, most continental land masses were clustered in the southern hemisphere, and Sri Lanka was part of the Gondwanaland landmass comprising present day Africa, Madagascar, India and Antarctica. Within the Ordovician (485.4-445.2Ma) to Permian Periods (299.0-254.2 Ma) there were signs of the breaking up of Gondwanaland resulting in the severing of India and Sri Lanka together and subsequently Sri Lanka from India. By end of the Permian Period (260 Ma) Karoo Glaciation had ended and the present Mannar Basin developed within a deep canyon (about 4-7 km deep) on the Precambrian basement.

Although the island of Sri Lanka presently lies in the Indian Ocean between $5^{\circ} 52^{\prime} \mathrm{N}-9^{\circ} 54^{\prime} \mathrm{N}$ and $79^{\circ} 30^{\prime} \mathrm{E}-81^{\circ} 55^{\prime} \mathrm{E}$, to the southwest of Bay of Bengal and southeast of Arabian Sea, it was positioned within $67^{\circ} \mathrm{S}-65^{\circ} \mathrm{S}$ and $34^{\circ} \mathrm{E}-43^{\circ} \mathrm{E}$ during the Lower and Middle Jurassic Era (201.3-166.1 Ma). Huge rocky blocks (erratic boulders) have been transported to different places by continental ice sheets due to climatic changes in the Permian, Triassic and Jurassic Periods, but erratic pebbles ( 2 to $8 \mathrm{~cm}$ or more in size) and streams fed deposits have been transported by glacifluvial processes. These glaciofluvial processes occurred on four occasions during the Jurassic Period and Eocene, Miocene and Pliocene Epochs on Sri Lankan landmass, which fallowed the climatic changes and sea level fluctuations that broke up the sedimentary beds, initiating establishment of the present topography and structural configuration. As a result, the earlier sedimentary deposits were obliterated from greater part of Sri Lanka. During the Quaternary Period the erosional rate increased and the resultant erratic boulders along with glaciofluvialdeposits can still be found on "Planated Surfaces"of Sri Lanka.
\end{abstract}

\section{Introduction}

From the time of initial accretion and differentiation (ca. $4560 \mathrm{Ma}$ ) to the first appearance of abundant hard-bodied fossils, the Precambrian Super Eon spans 88 percent of Earth history (Felix et al., 2004).Sri Lanka is a tropical island positioned between $5^{\circ} 50^{\prime} \mathrm{N}-9^{\circ} 55^{\prime} \mathrm{N}$ and $79^{\circ} 30^{\prime} \mathrm{E}-81^{\circ} 55^{\prime} \mathrm{E}$, southwest Bay of Bengal and southeast Arabian Sea in the Indian Ocean. Although Sri Lanka became a separate landmass during the Triassic-Jurassic Period (208.5-201.3 Ma), its history goes back to the Achaean Eon of the Precambrian Super Eon that is divided into six Eons, with boundaries defined by what can be considered first-order "watersheds" in the evolution of the Earth (Felix et al., 2004).

*Correspondence: katupotha@gmail.com

Tel: +94718011540 Fax: +94115524530

ISSN 2235-9370 Print / ISSN 2235-9362 Online C2013 University of Sri Jayewardenepura 
Sri Lankan rocks have been documented to be late Archaean to early Proterozoic $(3,200-2,400$ Ma) based on ages of detrital grains zircons obtained from Highland/Southwestern Complex (H/SWC) rocks. It is revealed that these rocks have a relationship with Precambrian events, and therefore to be the foundation rocks or basement rocks of Sri Lanka (Hölzlet al. 1991; Kröneret al. 1991). By the Paleoproterozoic Era (2,050 - 1,800 Ma), the rugged high ground occupying the Highland Complex (HC) of Sri Lanka (Cooray 1994) became characterized by a NW-SE and NE-SW trending sequence of highgrade metasediments and granuliticorthogneisses. Likewise, during the Mesoproterozoic Era (1600-1200 $\mathrm{Ma}$, orthogneisses of the Vijayan Complex (VC) were intruded between 1,040-1,030 Ma and orthogneisses of the Wanni Complex (WC) were intruded between 1,100-670 Ma. Moreover, by the Neoproterozoic Era between 610 and $550 \mathrm{Ma}$, the high-grade regional metamorphism of the HC, VC and WC took place within ultra-high temperature metamorphic rocks (Braun, 2003). All these Proterozoic rocks are the basement rocks of Sri Lanka.

In the Earth's history, there were five major glaciations, namely, the Huronian, Cryogenian or Sturtian-Varangian, Andean-Saharan, Karoo (Carboniferous and Permian Period) and the Quaternary that occurred between 2,300 and 0.0114 Ma (ICS 2009). It is accepted that Gondwanaland emerged between the Huronian Glaciation (2,300-2,100 Ma) in the Paleoproterozoic Era and the Andean-Saharan Glaciation (460-430 Ma) in the Early Paleozoic Era. Wanless and Cannon (1966) reported the events of Late Paleozoic Glaciation from India and Pakistan, Africa, South America, Australia, Antarctica, Madagascar and Falkland Islands. During these glacial times, most of the continental land masses mentioned above were clustered in the southern hemisphere, and the landmass of Sri Lanka remained joined to the landmass of Africa-Madagascar-India that was joined to Antarctica.

Although the present landmass of Sri Lanka lies southwest of Bay of Bengal and southeast of Arabian Sea, it was positioned within $67^{\circ} \mathrm{S}-65^{\circ} \mathrm{S}$ and $34^{\circ} \mathrm{E}-43^{\circ} \mathrm{E}$ during the Lower and Middle Jurassic Era (201.3-166.1 Ma). Climatic changes in the Permian, Triassic and Jurassic Periods huge rocky blocks (erratic boulders) have been transported to different places by continental ice sheets. Likewise erratic pebbles, smaller stones from 2 to $8 \mathrm{~cm}$ or more, andstreams fed deposits have been transported by glacifluvial processes (Table 1). This paper proposes that these glaciofluvial processes that occurred on four occasions namely, the Jurassic Period and Eocene, Miocene and Pliocene Epochs due to geologicand climatic changes and sea level fluctuationsbroke up the prevailing glaciofluvial sedimentary beds, giving rise to the present topography comprising, "Planated Surfaces", relict erratic boulders and ice-rafted or streams fed deposits. Quesnelet al. (2012) have proposed a geomorphologic classification of planation surfaces and inferred scenarios of vertical deformation and morphogenetic evolution by applying the planation surface concept, previously used for stable cratonsof western Africa, Australia and BrazilGuyana which endured glacial times.

This is the first attempt to postulate that Sri Lanka had endured glacial climate as revealed by the incidences of erratic boulders, erratic pebbles and streams fed deposits. Both erratic pebbles and stream fed deposits weredeposited from melt-water of the Karoo (Carboniferous - Permian Period, 360-260 Ma) glaciers since the Middle Triassic to the Early Eocene Period (247.2-56.0 Ma). By Early Eocene time, Sri Lanka was located between $18-24^{\circ} \mathrm{S}$ and $63-66^{\circ} \mathrm{E}$ (Table 1). In this effort, information gathered from detailed investigations of erratic boulders located along the coastal belt in the Eastern Province (Second Planated Surface) and erratic boulders and streams fed deposits of the Kurunegala District, Northwestern Province (Second and Third Planated Surfaces) further validated glaciation and climate change.

\section{Methodology}

In the Earth's history, glacial and interglacial periods have played a significant role in the evolution of continentsand palaeoclimate together with fauna and flora, ice-rafted and streams fed deposits etc.Poulsenet al (1977) present evidence that Late Paleozoic tropical climate responded to 
Gondwanan de-glaciation. There are also many geological, geomorphological, palaeontological and sedimentological evidences that can be found on land (from continents) and from oceanic sediment cores (Steiner and Wallick 1992). The prime motivation for writing this paper is to suggest a process for the evolution of its major planated surfaces and associated climate changes as a consequence of palaeodeglaciation revealed by the occurrence of glaciofluvial deposits.In this effort, information regarding size and dimensions of erratic boulders was gathered from detailed investigations during the period from November 2011 to March 2012 and September 2012 from in many localities within Colombo, Kurunegala,Trincomalee, Batticaloa and Ampara Districts.

\section{Results and Discussion}

The cyclic sedimentary sequences located in low latitudes in continental areas are interpreted as results of frequent changes in global sea levels associated with palaeo glacial cycles. Glacial cycles and variations in sea level are documented in oxygen-isotope and $p \mathrm{CO}_{2}$ variations (Horton et al. 2012). Due to such changes much of the Southern Hemisphere was covered by ice as glaciers pushed northward by Upper Permian time (298.9-279.3 Ma). Coal was produced in both Equatorial rainforests and in temperate forests during the warmer "Interglacial" periods (Table 1). Likewise, the equatorial rainforest disappeared as deserts spread across Central Pangaea during the Middle and Upper Permian periods. Although the southern ice sheets were gone, an ice cap covered the North Pole. Likewise, rainforests covered South China as it crossed the Equator. Sea levels in the Permian Period remained generally low, and near-shore environments were limited by the collection of almost all major landmasses into a single continent called Pangaea (ICS 2009).

Table 1: Showing the climate changes and other significant events in relation to glacial periods. The symbol • denotes events in Sri Lanka.

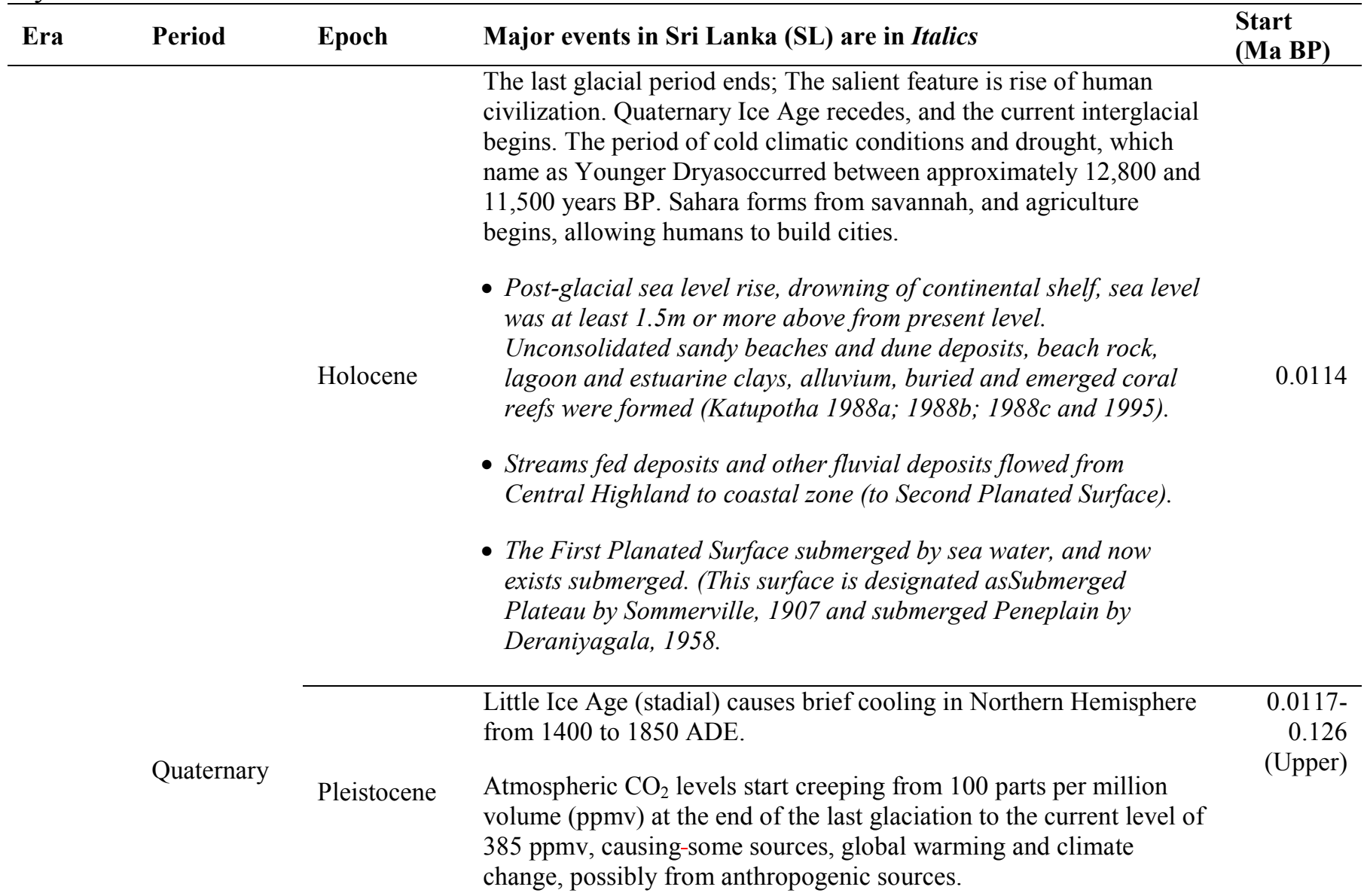


Flourishing and then extinction of many large mammals (Pleistocene mega-fauna).

0.781

Evolution of anatomically modern humans.

- Stranding evidence of sea level fluctuations, sand dunes, gravel deposits, formation of Red Beds, laterite, nodular ironstone (Katupotha 1995; Cooray 1984).

- Erratic pebbles, stream fed deposits and other terrestrial deposits flowed from Central Highland to coastal zone (to Second Planated Surface).

- $S L$ assuming present position between $5^{\circ} 52^{\prime} \mathrm{N}-9^{\circ} 55^{\prime} \mathrm{N}$ and $79^{\circ}$ $30^{\prime} E-81^{\circ} 55^{\prime} E$.

Intensification of present Icehouse conditions, present (Quaternary) ice age begins roughly $2.58 \mathrm{Ma}$; cool and dry climate.

Pliocene Australopithecines, many of the existing genera of mammals, and recent mollusks appear. Homo habilis appears.

- Marine colloidal sedimentation in northwestern SL.

Moderate Icehouse climate, punctuated by ice ages; Orogeny in northern hemisphere.

Widespread forests slowly draw in massive amounts of $\mathrm{CO}_{2}$, gradually lowering the level of atmospheric $\mathrm{CO}_{2}$ from 650 ppmv down to around $100 \mathrm{ppmv}$.

Neogene Miocene

- The Puttalam-Jaffna limestone in the northwest and Minihagalkanda beds in the southeast were deposited. By the Tortonian Stage(11.62-7.246 Ma) of the Miocene period, Sri Lanka had located itself at $4^{\circ} \mathrm{N}-8^{\circ} \mathrm{N}$ and $77^{\circ} \mathrm{E}-79^{\circ} \mathrm{E}$.

- By Mid Miocene (15.97-13.82 Ma), Sri Lanka was positioned between $0.30^{\circ} \mathrm{N}-4^{\circ} .30^{\prime} \mathrm{S}$ and $73^{\circ} \mathrm{E}-76^{\circ} \mathrm{E}$. Erratic boulders, erratic pebbles and stream fed deposits deposited at random on Second and Third Planated Surfaces.

Warm but cooling climate appeared on the Earth, moving towards Icehouse; rapid evolution and diversification of fauna, especially mammals. Major evolution and dispersal of modern types of

Oligocene flowering plants (ICS 2009).

- By Oligocene Period, Central Highland was covered by an ice cap, glaciers on Second and Third planated surfaceswere melting.

Moderate, cooling climate.

Re-glaciation of Antarctica and formation of its ice cap; and the Icehouse Earth climate that would follow it to this day. Lowering of

Paleogene atmospheric carbon dioxide from 3800 ppmv down to $650 \mathrm{ppmv}$ (ICS 2009).

Eocene $\quad$ 37.2 Ma, SL resided as an island within $9^{\circ}-13^{\circ} \mathrm{S}$ and $66^{\circ}-69^{\circ} \mathrm{E}$.

Himalayan Orogeny began between 52 and $48 \mathrm{Ma}$.

- At that time $S L$ was between $18^{\circ}-24^{\circ} S$ and $63-66^{\circ} E$.

- Possibility of the Fourth Planated Surface (Central Highlands) being covered by glaciers.

Paleocene Alpine Orogeny in Europe and Asia begins. Indian Subcontinent collides with Asia 55 Ma, Himalayan Orogeny starts between 52 and 58.7 
$48 \mathrm{Ma}(\mathrm{ICS}, 2009)$.

- $S L$ positioned between $31^{\circ} S-34^{\circ} S$ and $55^{\circ} E-58^{\circ} \mathrm{E}$

Break up of Gondwana. Beginning of Laramide and Sevier $100.5-$ Orogenies of the Rocky Mountains. Atmospheric $\mathrm{CO}_{2}$ close to

present-day levels.

- Between 100.5 Ma and 72.1 Ma (Upper Cretaceous) SL moved further north and east $\left(45^{\circ} \mathrm{S}-50^{\circ} \mathrm{S}\right.$ and $\left.53^{\circ} \mathrm{E}-56^{\circ} \mathrm{E}\right)$ rotating northerly.

Cretaceous

Jurassic

- Around 125.0-113.0 Ma SL was located within $45^{\circ} S-50^{\circ} S$ and $53^{\circ}$ E-56 E. Between $136 \mathrm{Ma}$ and $130 \mathrm{Ma}$ in Early Cretaceous, $S L$ rotated anticlockwise from ENE-WSW to NE-SW; SL located around $64^{\circ} S=66^{\circ} S$ to $33^{\circ} E-38^{\circ}$ E. At some stage during the Cretaceous period $(145.0=70.6 \mathrm{Ma})$ more than $850 \mathrm{~m}$ thick sandstones were deposited in the Mannar Basin.

- Evolution of "Post-Gondwana" highland landscapes (King 1962).

Upper Breakup of Pangaea into Gondwana and Laurasia. Nevadan Orogeny
in North America. Rantigata and Cimmerian Orogenies taper off. Atmospheric $\mathrm{CO}_{2}$ levels 4-5 times the present day levels (1200-1500 ppmv, compared to today's $385 \mathrm{ppmv}$ ).

Mesozoic

Middle

Lower

- SL detached from the southern supercontinentGondwanaland. The Indian Ocean began to open up. India and Sri Lanka's landmass separated from the Australia and Antarctica/Australia plate.

- During the Upper Jurassic Period SL was positioned within $65^{\circ} S$ $67^{\circ} \mathrm{S}$ and $32^{\circ} \mathrm{E}-36^{\circ} \mathrm{E}$. Tabbowa Beds (generally (arkoses) and Andigama-Pallama Beds (arkoses and carbonaceous shales with thin coal slivers) were formed locally onshore within faultbounded basins.

- SL emerged as a separate landmass.

\begin{tabular}{cc}
\hline & Upper \\
\cline { 2 - 2 } Triassic & Middle \\
\end{tabular}

Landmasses unite into supercontinent Pangaea, creating the Appalachians. End of Permo-Carboniferous glaciation.

Permian-Triassic extinction event occur $251 \mathrm{Ma}$ : $95 \%$ of life on Earth becomes extinct, including all trilobites, graptolites, and

Lower blastoids. Climate was generally hot and dry. Formed typical red bed
sandstones and evaporites. Large size of Pangaea limited the moderating effect of the global ocean. The Permian-Triassic extinction event (Great Dying) occurred 251.4 Ma ago (ICS, 2009). Sea levels in the Permian remained generally low, and near-shore Permian environments were limited by the collection of almost all major landmasses into a single continent - Pangaea (ICS 2009).

\section{Carbonifer-} ous/PennsyUralian Orogeny in Europe and Asia. Variscan Orogeny occurs towards middle and late Mississippian Periods.

lvanian ssippian Coal-forming coastal swamps.

Glaciation in East Gondwana. Tuhua Orogeny in New Zealand tapers off.

Devonian 


\begin{tabular}{ll}
\hline & Beginning of Caledonian Orogeny for hills in England, Ireland, \\
Wales, Scotland, and the Scandinavian Mountains. Also continued \\
into Devonian period as the Acadian Orogeny, above. Taconic \\
Orogeny tapers off. Lachlan Orogeny on Australian Continent tapers \\
off. \\
Gondwana emerges. Petermann Orogeny on the Australian \\
Continent tapers off (550-535 Ma). Ross Orogeny in Antarctica. \\
Atmospheric $\mathrm{CO}_{2}$ content roughly 20-35 times present-day \\
(Holocene) levels (6000 ppmv compared to today's 385 ppmv) and \\
Ice age at end of period (ICS, 2009). \\
- From Ordovician (488.3-445.6Ma) to Permian (299.0 - 253.8 Ma) \\
there were breaking up signs of Gondwanaland, including between \\
Sri Lanka and India. \\
- Present Mannar Basin developed as a deep canyon (about $4 \mathrm{~km}$ \\
deep) on the Precambrian basement. \\
542 - 496 Ma, the Gondwanaland emerges. Most continental land \\
masses were clustered in the southern hemisphere (ICS 2009). \\
- SL remained joined with the landmass composed of Africa, \\
Madagascar" India and Antarctica. \\
Joining East Gondwanaland to West Gondwanaland (ICS 2009).
\end{tabular}

Source: See References Cooray 1984; ICS 2009 (Retrieved 2009-09-25); Katupotha 1988a, 1988b, 1988c and 1995; King 1962; Sommerville, 1907 and Deraniyagala, 1958.

In Sri Lanka, nearly $90 \%$ of its rock types are composed of crystalline Precambrian metamorphic rocks. They are subdivided as Highland Complex, Wanni Complex and Vijayan Complex and other small divisions (Cooray, 1984, 1994; Hölzlet al. 1991, Kröneret al. 1991). Meta-igneous rocks (charnockites, hornblende-biotite gneiss, migmatitic and quartzofeldspathic rocks) and metasedimentary rocks (quartzites, marble/dolomite and garnet-sillimanite-graphite schist) are major rock types of the Highland Complex. The Vijayan Complex lies east of the Highland Complex. It is composed of metamorphosed granitoids, charnockitic gneisses, migmatites, microcline-bearing quartzofeldspathic rocks, amphibolite and/or biotite gneiss. The Wanni Complex located west of the Highland Complex is composed of rock types more or less similar to those of the Vijayan Complex. In addition, a small unit named "Kadugannawa Complex" composed of amphibolite or hornblende-biotite gneisses and migmatitesis located in the central part of the country.

The other remaining rocks $(\sim 10 \%)$ consist of Jurassic sandstones, shales and mudstones, some exposed in faulted basins at Tabbowa and Andigama, and Miocene limestone lying unconformably on the Precambrian basement of the North, Northwestern and Southeastern coastal belts (Cooray, 1984; Katupotha and Dias, 2001). Geologically, the Jurassic Period is extremely important to Sri Lanka.

Prior to Jurassic, at the end of the Paleozoic the Earth's surface was characterized by a relatively simple landmass configuration with three main continents (Gondwanaland, Laurasia and Angaraland) coalescing to form the Pangean supercontinent. The oceanic domain was defined in its major part by Panthalassa and partially by the Tethys. No major geographic rearrangement of continents and oceans has been documented for the Permian-Triassic transition and for the Lower Triassic, except for the northward motion of entire Pangaea (Galfetti, et al, 2007). During the Triassic which extends about 252.2 to 208.5Ma and Global climate was warm during the Upper Triassic. There was no ice at either North or South Poles. Warm Temperate conditions extended towards the poles.

The Pangaea Mega-monsoon was in full swing during the Lower and Middle Jurassic (Jinnan and Parrish 1999). The interior of Pangaea was very arid and hot. Deserts covered what is now the Amazon and Congo rainforests. China, surrounded by moisture bearing winds was lush and verdant. During the 
Upper Jurassic (163.5-152.1 Ma) the global climate began to change due to the break-up of Pangaea. The interior of Pangaea became less dry, and seasonal snow and ice frosted the Polar Regions. By Lower to Middle Jurassic (201.3-166.1Ma), Sri Lanka emerged as a separate landmass positioned within $52^{\circ} \mathrm{S}-55^{\circ} \mathrm{S}$ and $17^{\circ} \mathrm{E}-22^{\circ} \mathrm{E}$.

Sri Lanka reached its present position at $5^{\circ} 52^{\prime} \mathrm{N}-9^{\circ} 55^{\prime} \mathrm{N}, 79^{\circ} 30^{\prime} \mathrm{E}-81^{\circ} 55^{\prime} \mathrm{E}$, by Lower to Middle Pleistocene (1.806-0.781 Ma). During this drifting period from Lower to Middle Jurassic, Sri Lanka was subjected to at least four major upliftments through Jurassic, Miocene, Pliocene and Pleistocene times (Wayland 1919, Deraniyagala 1958, Cooray1984). As an 'Upliftment' in geological terms, is a consequence of tectonic activity, this author is of the view that such major upliftments did not occur for the formation of "The face of Sri Lanka" during this geologic period, and proposes a new "Planation Surface Concept" together with minor tectonic activity to reconstruct the morphogenesis of Sri Lanka's topography based on glacial events during drifting of Sri Lanka from the southern hemisphere to the northern hemisphere. Accordingly, it is possible to identify "Four Major Planated Surfaces" developed in response to climatic and sea level fluctuations, which followed the glaciations and de-glaciations. Such events broke up the existing glaciofluvialsedimentary beds transforming the topography and structure of Sri Lanka. At present, the "First Planated Surface" is now submerged (Figure 1), which has been identified as a 'submerged plateau' by Sommerville (1907) and submerged peneplain by 'Deraniyagala (1958).

Sedimentary rocks of the Upper Jurassic age in north-west Sri Lanka are preserved in at least three faulted basins within the crystalline Vijayan Complex (Table 1). For example, Tabbowa Beds (generally arkoses) and Andigama-Pallama Beds arkoses and carbonaceous shales with thin coal slivers) were formed locally onshore within fault-bounded basins (Cooray 1984). One of these basins, that on the west of Tabbowa Tank, $12.8 \mathrm{~km}$ from Puttalam on the road to Anuradhapura, is exposed at the surface. The shales, which are at Andigama and Pallama, about 21 and $43 \mathrm{~km}$ respectively due south of Tabbowa, are completely covered by later deposits. Similar deposits lie almost in a straight line with similar faulted basins near Chennai on the east coast of Peninsular India, nearly $320 \mathrm{~km}$ to the north, and it is probable that all these Jurassic sediments were deposited at the same time (Cooray 1984). The sediments were laid down on the margins of Gondwanaland which included parts of what are now known as India, Australia, Antarctica, South America, Africa and Madagascar. By the Upper Jurassic Period Sri Lanka was detached from the southern supercontinent Gondwanaland, and the Indian Ocean began to open up. The landmasses of India and Sri Lanka separated from Australia and the Antarctica/Australia plate.As the climate warmed up the glacial meltwater deposited the coarser material near the terminal end of the glacierand the finer material further away. Such phenomena are salient features of paleoclimate of Sri Lanka.

The Lower Cretaceous (145.5-113.0 Ma) was a mild "Ice House" world (ICS, 2009). There was snow and ice during the winter seasons, and cool temperate forests covered the Polar Regions. During the Upper Cretaceous the global climate was warmer than today's climate. No ice existed at the Poles. Dinosaurs migrated between the Warm Temperate and Cool Temperate Zones as the seasons changed. "Post-Gondwana" highland landscapes in Sri Lanka emerged (King 1962). At some stage during the Cretaceous period (145.0-72.1Ma) more than 850m thick sandstones were deposited in the Mannar Basin. Between 145.0 Ma and 113.0 Ma, in Lower Cretaceous, Sri Lanka rotated anticlockwise from ENE-WSW to NE-SW while translocating northwards from $58^{\circ} \mathrm{S}-60^{\circ} \mathrm{S}$ to $13^{\circ} \mathrm{E}-16^{\circ} \mathrm{E}$. By Upper Cretaceous Sri Lanka moved further north and east to a position within $54^{\circ} \mathrm{S}-57^{\circ} \mathrm{S}, 30^{\circ} \mathrm{E}-35^{\circ} \mathrm{E}$. Due to these changes,namely, anticlockwise rotation and northward movement Sri Lanka's "Second Planated Surface" (present surface including the coastal plain) was formed by extensive retreating glaciers again (Figure 1). Similarly, the "Third PlanatedSurface" and the "Fourth Rugged Central Highland" of Sri Lanka emerged due to thawing of massive glaciers (Figure 1), which covered Central Highland and Third Planation Surface since Palaeocene to Oligocene Periods. Within these periods, Sri Lanka moved from $31^{\circ} \mathrm{S}-34^{\circ} \mathrm{S}$ and $55^{\circ} \mathrm{E}-58^{\circ} \mathrm{E}$ to $9^{\circ} \mathrm{S}-13^{\circ} \mathrm{S}$ and $66^{\circ} \mathrm{E}-69^{\circ} \mathrm{E}$ passing the Tropic of Capricorn. 


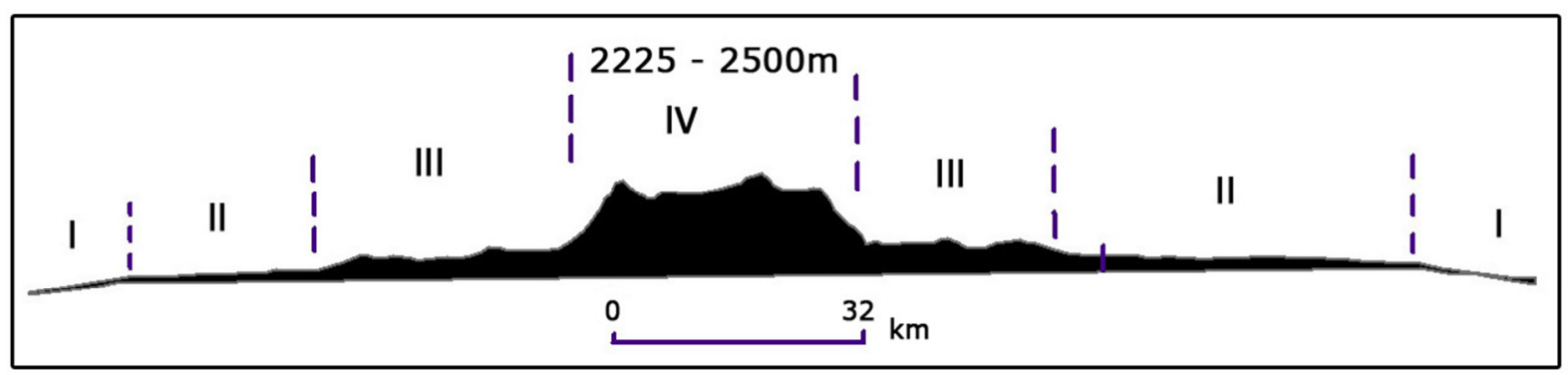

Figure 1: Diagrammatic section across Sri Lanka from west to east showing the four planated surfaces. I - first (submerged), II- second (Flat terrain to Undulating terrain, Rolling and Hilly Terrains, III - third (Dissected Rolling and Hilly; Steeply Dissected Rolling and Hilly Terrains, and IV - fourth (Mountainous and Rugged Central Highland)

With the emergence of Planated Surfaces and Central Highland of Sri Lanka as Third and Fourth Planated Surfaces, important depositional features of glaciofluvial origin including outwash plain, valley terrains, erratic boulders, ice-rafted deposits (eskers and tills), kames and kame terraces and streams fed deposits were formed. The climate during the Miocene was similar to today's climate, but warmer. Welldefined climatic belts stretched from Pole to Equator and continents continued to drift toward their present positions. King (1962) postulated that the extreme planation of plateau in Sri Lanka, survived only on smooth ridges or crests. This would be the "Third Planated Surface" in the country. Antarctica continued to become more isolated and finally developed a permanent ice cap (ICS 2009). By the end of the Oligocene Period Sri Lanka reached $2^{\circ} \mathrm{E}-7^{\circ} \mathrm{S}$ and $73^{\circ} \mathrm{E}-76^{\circ} \mathrm{E}$ and passed the Equator by Mid Miocene $\left(15.97-13.82 \mathrm{Ma}\right.$ ) with the position around $0.3^{\circ} \mathrm{N}-4.30^{\circ} \mathrm{N}$ and $73^{\circ} \mathrm{E}-76^{\circ} \mathrm{E}$ (Table 1).

As a result of the Pliocene-Quaternary climate changes the earlier glacial sedimentary deposits in Sri Lanka disappeared from the greater part of Sri Lanka and at present such deposits can be identified as patches from several parts of the country.There are no Pleistocene glacial deposits have been reported, because by the Quaternary Period, Sri Lanka had already reached its present position. However, scattered erratic boulders and patches of old ice-rafted deposits from former glacial depositions such as, outwash plains, valley terrains, kames and kame terraces can be identified throughout on first, second and third planated surfaces, although most are worn to shadows.

As a glacial deposit, an erratic is a piece of rock that differs from the size and type of rock native to the area in which it rests. Erratics can range in size from pebbles to large boulders such as big rocks (hundreds to thousands of metric tons in weight). Geologists identify erratics by studying the compositions and orientation of surrounding rocks in comparison to the composition and orientation of the erratic itself.Clast petrology(grains of sediment, silt, sand, gravel, etc), provenance and shape data for the Middle Pleistocene glaciofluvial sand and gravel of the Mníšek member have been discussed by Nývlt and Hoare (2011). The results are compared with those for in situ weathered bedrock debris and recent fluvial sediments from the same area. The results of this study would be helpful to investigate glaciofluvial sediments in Sri Lanka.

Due to the Pliocene-Quaternary climate changes, the earlier glacial sedimentary deposits in Sri Lanka have disappeared from greater part of Sri Lanka. However, there are no Pleistocene glacial deposits in Sri Lanka, but scattered erratic boulders and patches of ice-rafted deposits can be identified as glacial deposits older than Pleistocene Glaciation. Likewise, outwash plain type landforms can be identified from the "Second and Third Planated Surfaces", while valley terrains can be identified from the upper part of the "Third Planated Surface" and from the "Rugged Central Highland" area.

Erratics are significant because since they are transported by glaciers, they are one of a series of indicators which mark the path of glacier movement. Their lithographic origin can be traced to the parentrock, allowing for confirmation of the ice-sheets flow route. Similarly they can be transported by 
ice-rafting. Ice-rafted debris or ice-rafted deposits and stream feddeposits were deposited onto the bottom of the water body, for example, onto a river bed or an ocean floor. Erratic boulders at Tennamavadi are located at coordinates $8^{\circ} 58^{\prime \prime} \mathrm{N}$ and $80^{\circ} 58^{\prime} \mathrm{E}$ in Sri Lanka's Northeastern Coastal Zone very close to the present coast. The locality is about $15-20 \mathrm{~m}$ above MSL and $1.5 \mathrm{~km}$ southwest of Kokkilai Lagoon mouth, (Figure 1). Colour and mineral composition indicate that the rocks are derived from the Highland Complex rocks. They are mainly quartzite, marbles, garnet-sillimanite-schist and chanockitic gneisses. The erratic boulders at Valaichchenai Lagoon (coordinates $7^{\circ} 56^{\prime} \mathrm{N}, 81^{\circ} 33^{\prime} \mathrm{E}$ ), and Uraniya (Pottuvil) Lagoon (coordinates $6^{\circ} 53^{\prime} \mathrm{N}, 81^{\circ} 50^{\prime} \mathrm{E}$ ) are about $2.0 \mathrm{~m}-4.0 \mathrm{~m}$ above MSL (Figure2). The lithology of these boulders being composed of a heterogeneous group of gneisses, migmatites and granites with scattered sedimentary bands confirm the source to be Highland Complex rocks (Cooray 1984). The erratics exhibit rounded, oval and elongated shapes ranging in from pebbles to large boulders hundreds to thousands of metric tons in weight. These appear to have been dropped on rock outcrops or on the ground by melting glaciers moving in a northeasterly direction.

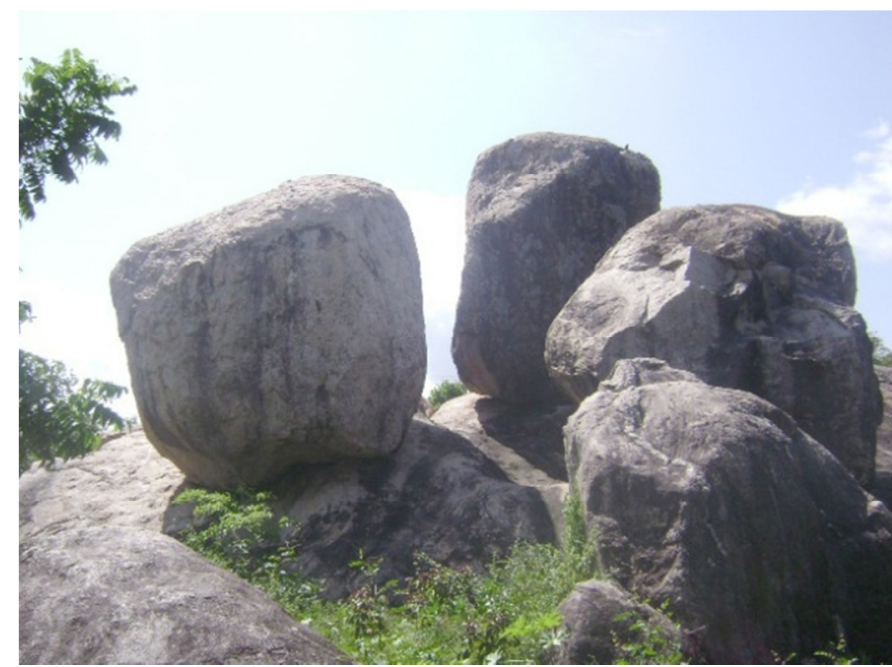

Figure 1: Showing erratic boulders at Tennamavadi (coordinates $8^{\circ} 58^{\prime} \mathrm{N}, 80^{\circ} 58^{\prime} \mathrm{E}$ ), about $1.5 \mathrm{~km}$ southwest of Kokkilai Lagoon mouth, $15-20 \mathrm{~m}$ above MSL in Northeast coast.

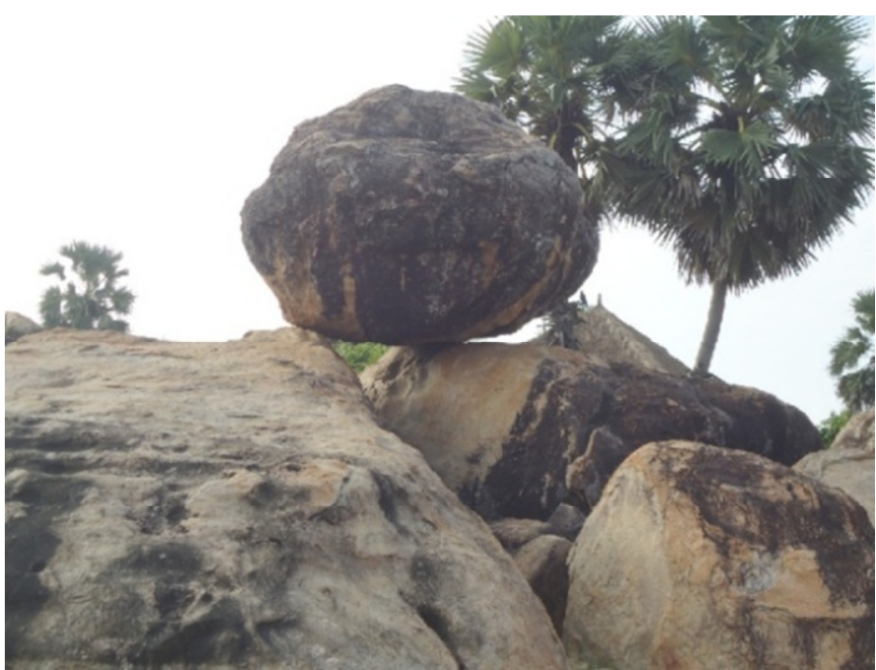

Figure 2: Showing erratic boulders at Uraniya (Pottuvil) Lagoon (coordinates $\left.6^{\circ} 54 \mathrm{~N}, 81^{\circ} 50^{\prime} \mathrm{E}\right), 3 \mathrm{~m}$ above MSL, East coast.

Erratic boulders at Kadigawa (coordinates $7^{\circ} 42^{\prime} \mathrm{N}$ and $80^{\circ} 00^{\prime} \mathrm{E}$ ) and Kadigawa Temple area (coordinates $7^{\circ} 43^{\prime} \mathrm{N}$ and $80^{\circ} 00^{\prime} \mathrm{E}$ ) in the Kurunegala DistrictNorthwestern Province are located on the Second Planated Surface. The area is $35-40 \mathrm{~m}$ above the present MSL. Erratic boulders at Nakolagane Temple site (coordinates $7^{\circ} 48^{\prime} \mathrm{N}$ and $80^{\circ} 18^{\prime} \mathrm{E}$, Photograph 4) and erratic boulders at Viharagala Temple site (coordinates $7^{\circ} 46^{\prime} \mathrm{N}$ and $80^{\circ} 28^{\prime} \mathrm{E}$, Figure3) in the Kurunegala District, Northwestern Province are located above 120 to 200m MSL. The boulders of the Northwestern Province are derived from the rocks of Highland and Wanni Complexes. The Wanni Complex is composed mainly of quartzites, calc-silicate gneisses, cordierite gneisses, garnet-sillimanite gneisses, garnet-biotite gneisses, quartzofeldspathic gneisses, metagranites (including pink granites), granitoid gneisses, charnockites, meta-diorite, amphibolites, meta-gabbros, migmatites, monzo-diorite and pegmatites.

Premarathne and Jayasena (2009) report that the hillocks named Weudakanda and Erapolakanda in the KurunegalaDistrict are covered with residual and colluvial soils. Some of these soils are reddish brown in color. Sub-aerial tropical weathering may have converted the original transported materials to iron-rich brown and reddish brown earth. An alternate statement proposed is "Descending from Weuda towards the western coast in the northwest plain, several intriguing isolated deposits were encountered immediately hinterland of the coastal area." They are the white sand deposits of Nattandiya and its nearby 
areas and ferruginized, indurated gravel bearing deposits exposed at Erunwela, Muttibendivila, Pallama, Metiyagane and (in the subsurface of hummocks throughout the lower plains in the northwest (Wayland 1919, Coates 1935, Deraniyagala 1958, Cooray 1963 and 1984). The original transported materials were converted to iron-rich brown and reddish brown earth embedded with well rounded quartz gravel to pebble size are found in a hummocky area at Leekolawewa in the Kurunegala District (Photograph 5). The sizes of the well rounded and oval shaped pebbles and cobbles vary from $2.0 \mathrm{~cm}$ to $8.0-10 \mathrm{~cm}$. This author believes that these sediments represent weather-worn outwash plain deposits produced at several stages during the glacial history.

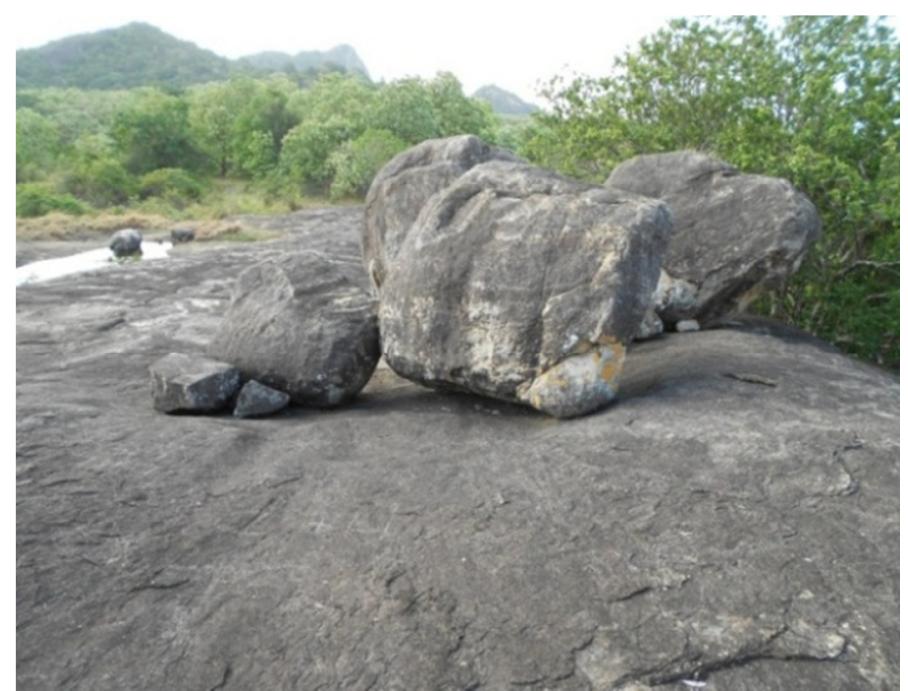

Figure 3: Erratic boulders at Viharagala Temple site (coordinates $\left.7^{\circ} 46^{\prime} \mathrm{N}, 80^{\circ} 28^{\prime} \mathrm{E}\right)$.

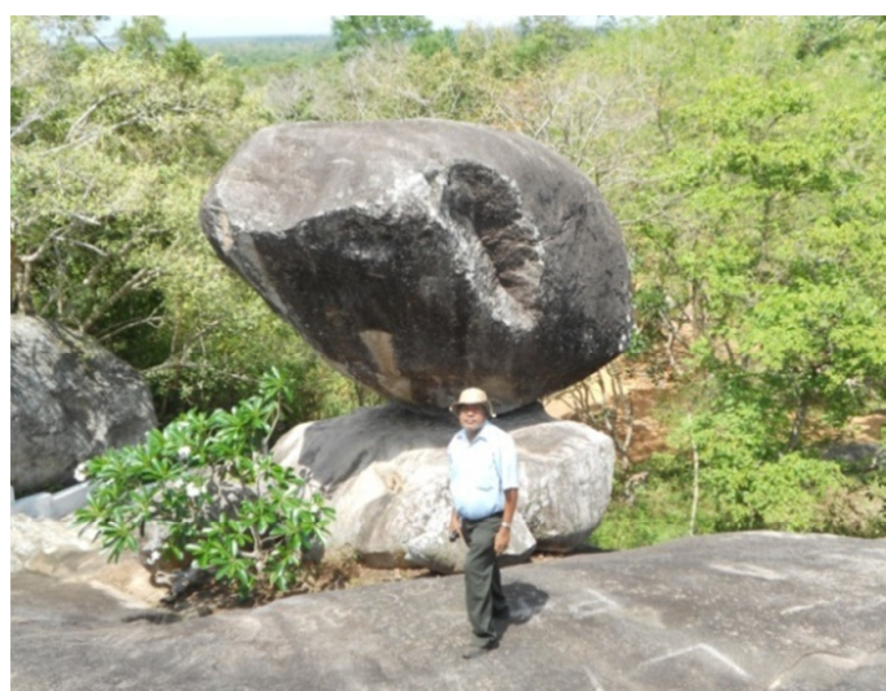

Figure 4: Erratic boulders at Nakolagane Temple site (coordinates $7^{\circ} 49^{\prime} \mathrm{N}, 80^{\circ} 19^{\prime} \mathrm{E}$ ) both in Kurunegala District.

Between Kaduwela and Hanwella on the Kelani Ganga (Western Province), for example, a highlevel gravel known as the "Malwana formation" is present at $16 \mathrm{~m}$ above the present river level $(28 \mathrm{~m}$ above MSL); a lower gravel, the Ranale formation, is found at $6.5 \mathrm{~m}$ above the present river level $(23 \mathrm{~m}$ above MSL; Photograph 6). The Malwana formation contains beds of well rounded, coarse quartz pebbles embedded in a matrix of laterite separated from each other by pebble-free layers of laterite. Remnants of this formation are seen capping the ridge that runs parallel with the river in Ranale and Nawagamuwa villages on the left bank of the Kelani Ganga (river), and at Mapitigama, Weelgama, Thittapattara, and Wiyalananda villages on the right bank of the same river (Cooray 1984).

The Ranale gravel forms a terrace about a $1-2 \mathrm{~km}$ wide and at a height between $10-25 \mathrm{~m}$ above MSL. It is about 3-4m thick probably formed as ice-rafted palaeo deposits during the progressive lowering of the river valley at a later stage. Outcrops of these gravels can be seen at several scattered locations along the valley on either side of the Kelani River, some of them being away from its present course. Well rounded and polished quartz pebbles, about $2.0 \mathrm{~cm}$ to $8.0 \mathrm{~cm}$ in size, embedded in a matrix of laterite separated from each other by a pebble-free layer of laterite is shown. These erratic boulders and ice-rafted deposits can be correlated with the pattern of sedimentation during the Late Paleozoic, Gondwanaland Glacial sediment from the Talchir Formation, Satpura Gondwana basin, central India (Chakraborty and Ghosh, 2008). 


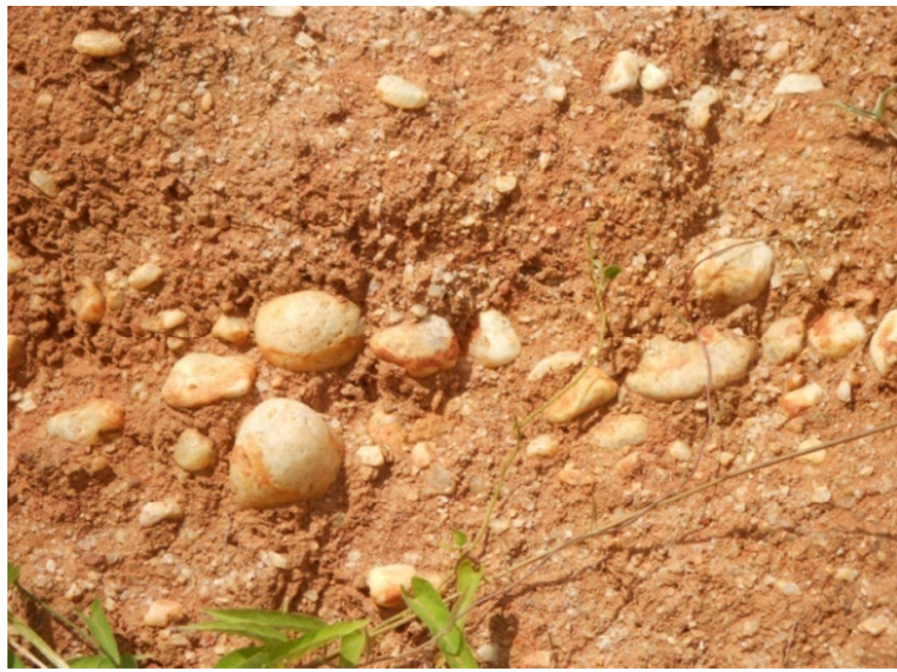

Figure 5: A gravel hummock at Leekolawewa (coordinates $7^{\circ} 42^{\prime} \mathrm{N}, 80^{\circ} 02^{\prime} \mathrm{E}$ ), about $40 \mathrm{~m}$ above MSL, in Northwestern Province.

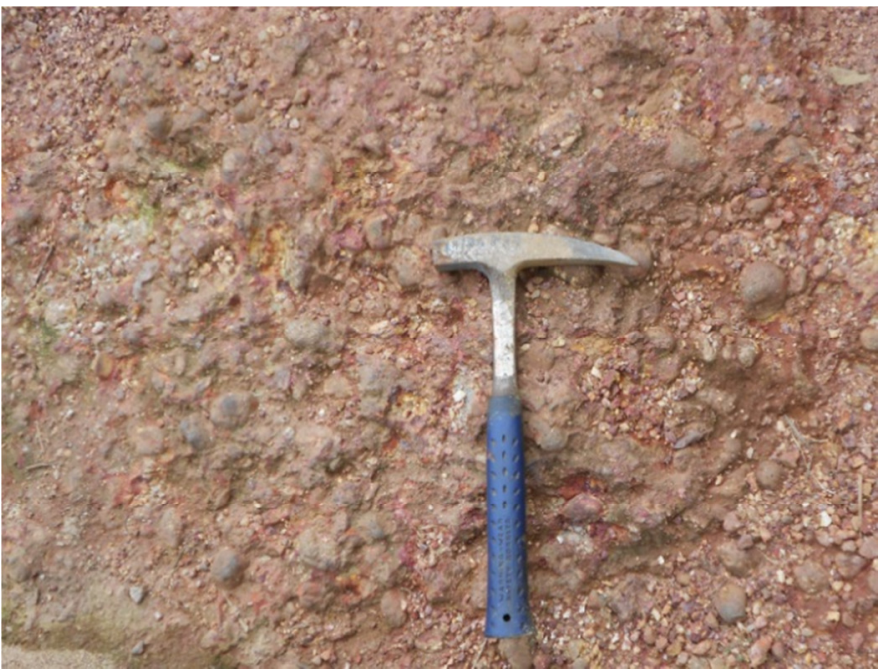

Figure 6: Ranale Gravel Deposit (coordinates $\left.6^{\circ} 55^{\prime} \mathrm{N}, 80^{\circ} 02^{\prime} \mathrm{E}\right), 22 \mathrm{~m}$ above MSL in Western Province (as streams fed deposits)

\section{Conclusion}

Climate changes and variations in sea level, which followed the glacial cycles from Huronian glaciation to Karoo glaciation in the Southern hemisphere continued during the northward drift of the landmass. Due to such changes, much of the Southern Hemisphere remained covered by ice as glaciers pushed northward during the Lower Permian time (299.0-279.3 Ma. By Lower Triassic (252.0-251.2) Ma, the interior of Pangea was hot and dry and warm temperate climates extended to the Poles. In due course, the interior of Pangaea became less dry, and seasonal snow and ice frosted the Polar Regions.

Sri Lanka emerged as a separate landmass between201.3 and 166.1 Ma (Lower and Middle Jurassic), when the landmass was positioned within $52^{\circ} \mathrm{S}-55^{\circ} \mathrm{S}$ and $17^{\circ} \mathrm{E}-22^{\circ} \mathrm{E}$. Sri Lanka reached its present positionwithin $5^{\circ} 52^{\prime} \mathrm{N}-9^{\circ} 54^{\prime} \mathrm{N}$ and $79^{\circ} 30^{\prime} \mathrm{E}-81^{\circ} 55^{\prime} \mathrm{E}$ at sometime between Lower and Middle Pleistocene

Although many workers proposed that Sri Lanka was subjected to at least four major upliftments during Jurassic, Miocene, Pliocene and Pleistocene times, this author is of the opinion that such major upliftmentsdid not occur during the said geologic periods, and instead introduces the new "Four Major Planation Surface Concept" to interpret the morphogenesis of Sri Lanka leading to its present topography based on major glacial events during drifting of Sri Lanka from the southern to the northern hemisphere.

The concept of "Four Major Planation Surfaces" states that pervasive climatic changes and significant sea level fluctuations that occurred since Jurassic, Miocene, Pliocene and Pleistocene times led to the brake up of glaciofluvialsedimentary beds altering the country's topography and structural configuration. The Pliocene-Quaternary climates changes appear to have obliterated earlier glacial sedimentary deposits from greater part of Sri Lanka. Despite no Pleistocene glacial deposits have been recorded, scattered erratic boulders without proper direction and patches of relict erratic pebbles or stream fed deposits can be identified near the coastal zone (Second Planated Surface). In addition, the Second and Third Planated Surfaces as well as the Rugged Central Highlands of Sri Lanka (Fourth Planated Surface), together with glacial deposits that are older than those of Pleistocene Glaciation provide conclusive evidence for Sri Lanka had endured palaeoclimatic changes and glaciations. 


\section{Acknowledgments}

My profound thanks go to Mr Nimal Ranasinghe, former Director, Geological Survey Department of Sri Lanka and Dr. Risto Hamari, Pahnakalliontie 4 C 14, 48400 Kotka, Finland for their pertinent suggestions and editing of the manuscript. I am deeply grateful to Professor Gamini Adikari, Director General, Central Cultural Fund of Sri Lanka and International Water Management Institute (IWMI) for providing ready assistance for all field visits, and also this study has been completed based on the Research and Development Allowance paid by University (Management Services Circular No: 44 and the Letter of UGC/C/PS/7 - dated 14 March, 2011).

\section{References}

ChakrabortyChandan and GhoshSanjoy Kumar., 2008. Pattern of sedimentation during the Late Paleozoic, Gondwanaland glaciation: An example from the Talchir Formation, Satpura Gondwana basin, central India. Journal of Earth System Science, Vol. 117, No. 4, August 2008, pp. 499-519.

Cooray, P.G., 1963. The Erunwela gravel and the probable significance of its ferricrete cap. Ceylon Geographer, 17: 39-48.

Cooray, P.G., 1984. An Introduction to the Geology of Sri Lanka (2nd Edition), National Museum of Sri Lanka Publication, Colombo, $340 \mathrm{p}$.

Cooray, P.G., 1994. The Precambrian of Sri Lanka: a historical review (Abstract). Precambrian Research 66, (1-4), February 1994, Pages 3-18

Caputo, M.V. and Crowell, J.C. 1985. Migration of glacial centers across Gondwana during Paleozoic Era (Abstract). Geological Society America, Bulletin 96:1020-1036.

Dahanayake, K., and Dassanayake, D.M.S.M., 1981. Glacial Sediments from Weuda Sri Lanka, Sedimentary Geology 30, 1-14.

Deraniyagala, P.E.P., 1958.The Pleistocene of Ceylon, Ceylon. National Museum Publication, Colombo. 1956; pp: 1-16.

Dubiel F. Russell, Parrish Judith Totman, Parrish J. Michael and Good C. Steven., 1991. The PangaeanMegamonsoon.Evidence from theUpper Triassic Chinle Formation, Colorado.pp 347-370.

Felix M. G., James G. O., Alan G. S., Wouter, B., Lucas J. L., 2004.A new Geologic Time Scale, with special reference to Precambrian and Neogene. Episodes, 27, 2.pp 83-100.

Hölzl, S., Köhler, H., Kröner, A., and Liew, T.C., 1991.Geochronology of the Sri Lankan basement. In: Kröner, A. (ed.), The crystalline crust of Sri Lanka, Part 1: Summary of Research of the German-Sri Lanka consortium, Geological Survey Department of Sri Lanka, Professional Paper 8. 1991: pp. 237 257.

Horton E Daniel, Christopher J. Poulsen, Montañez P. Isabel and William A. DiMichele., 2012.Eccentricity-paced late Paleozoic climate change.Palaeogeography, Palaeoclimatology, Palaeoecology 331-332 (2012) 150-161.

ICS., 2009. International Stratigraphic Chart, Retrieved 2009-09-25. International Commission on Stratigraphy, available at: http://www.stratigraphy.org/chus.pdf.

Jinnan Tong and Parrish J.T., 1999. The Pandean megamonsoon and climate change in south China during the Triassic. Proceedings of the International Conference on Pangea and the PaleozoicMesozoic Transition, March 9-11,1999.

Katupotha, J., 1988a. Evolution of the coastal landforms in the western part of Sri Lanka. Geographical Sciences (Hiroshima Univ.), V 43 (1), 18-37.

Katupotha, J., 1988b. Hiroshima University radiocarbon dates 1, west and south coasts of Sri Lanka. Radiocarbon, 30(1): 125-128.

Katupotha, J., 1988c. Hiroshima University radiocarbon dates 2, west and south coasts of SriLanka. Radiocarbon, 30(3): 341-346. 
Katupotha, J. 1995: Evolution and geological significance of Holocene emerged shell beds on the southern coastal zone of Sri Lanka. Journal of Coastal Research, 11 (4), 1042-1061.

Katupotha, J. and Dias, P., 2001. The Geological Evolution Correlated to the Stratigraphy of theKalpitiya Peninsula. Journal of Indian Association of Sedimentalogists. 20(1), 21-37.

King, L. C., 1962.The Morphology of the Earth.Oliver and Boyd, Edinburgh and London.pp 324-326.

Kröner, A., Cooray, P.G., and Vitanage, P.W., 1991.Lithotectonic subdivision of the Precambrian basement in Sri Lanka. In: Kröner, A. (ed.). The crystalline crust of Sri Lanka. Part 1: Summary of Research of the German-Sri Lanka consortium, Geological Survey Department of Sri Lanka, Professional Paper 8. 1991; pp. 5-21.

Nývlt, D. \& Hoare, P. G., 2011: Petrology, provenance and shape of clasts in the glaciofluvial sediments of the Mníšek member, northern Bohemia, Czechia. Sbor.geol. Věd, Antropozoikum, 27, 5-22.

Poulsen J Christopher, Isabel Pollard David, Montañez, P and Rowley David., 1977.Late Paleozoic tropical climate response to Gondwanandeglaciation.Geology, 35(9), 771-774.

Premarathne D.M.U.A.K. and Jayasena H.A.H., 2009.Paleozoic glacial sediments of Sri Lanka obliterated by Neotectonicevents?Weuda deposits revisited. Journal of Geological Society of Sri Lanka Vol. 13 (2009), 105-111.

Quesnel, F., Barbarand, J., Sevin, B., Ricordel-Prognon, C., Cluzel, D., Maurizot, P., Gautheron, C., 2012. Can we use the planation surface concept to reconstruct the morphogenesis of New Caledonia, First low temperature thermochronologicaldata. 34th International Geological Congress, Brisbane: Australia.

Steiner B Maureen and Wallick P Brian., 1992. Jurassic to PaleocenePaleolatitudes of the Pacific Plate derived from the paleomagnetism of the sedimentary sequences at sites 800, 801, and 802 (23). In Larson, R. L., Lancelot, Y., et al., 1992. Proceedings of the Ocean Drilling Program, Scientific Results, Vol. 129, 431-446.

Sommerville, B. T., 1907. The submerged plateau surrounding Ceylon, SpoliaZeylanica 5 (18), 69-79.

Vitanage P.W., 1972. Post Precambrian uplift and Regional Neotectonic Movements in Ceylon, Proc 24th IGC, Section 3, Montreal, 642-653.

Wanless, R. Harold and Cannon R. Julie., 1966. Late paleozoic glaciations. Earth-Science ReviewsVolume 1, Issue 4, May 1966, Pages 247-286

Wayland, E.J., 1919. Outline of the stone age of Ceylon. SpoliaZeylanica, 11, 85-125. 